\title{
Neurofibromatosis type 2
}

\author{
S. Sathornsumetee, MD; A. DesJardins, MD, FRCP(C); D.A. Reardon, MD; \\ J.N. Rich, MD; and J.J. Vredenburgh, MD
}

A 45-year-old woman developed a gradual onset of sensorineural hearing loss in the left ear in 1984. Head CT scan with contrast demonstrated bilateral cerebellopontine angle (CPA) enhancing masses. She underwent a resection of the left CPA tumor with pathology confirming schwannoma. Despite several resections, she had progressive hearing loss and she became deaf in 2003. Her brain MRI (figure) demonstrated bilateral vestibular schwannomas, which are sufficient for a definite diagnosis of neurofibromatosis type 2 (NF-2), according to the National Institutes of Health, Manchester, or National Neurofibromatosis Foundation diagnostic criteria. ${ }^{1}$ In addition, this patient also has multiple meningiomas, which are associated with NF-2. ${ }^{2}$ The patient has been treated with imatinib mesylate (Gleevec) plus hydroxyurea in a clinical trial for her progressive meningiomas. At her last follow-up visit, she was neurologically and radiographically stable after 12 months of treatment.

\section{References}

1. Baser ME, Friedman JM, Wallace AJ, Ramsden RT, Joe H, Evans DG. Evaluation of clinical diagnostic criteria for neurofibromatosis 2. Neurology 2002;59:1759-1765.

2. Antinheimo J, Sankila R, Carpen O, Pukkala E, Sainio M, Jaaskelainen J. Populationbased analysis of sporadic and type 2 neurofibromatosis-associated meningiomas and schwannomas. Neurology 2000;54:71-76.

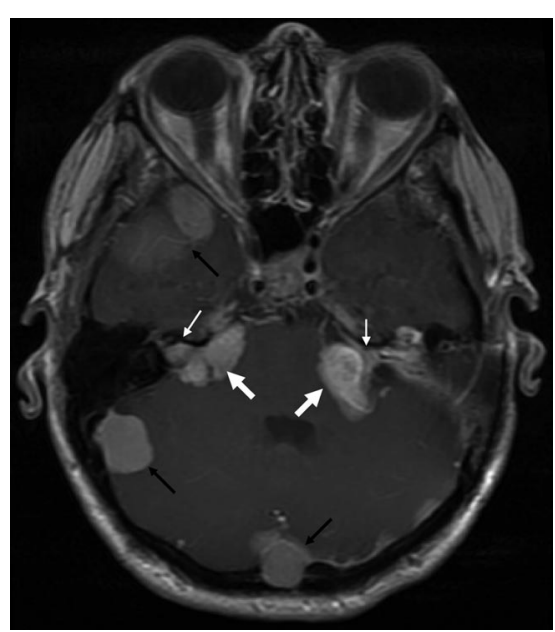

Figure. T1-weighted MRI revealed large gadolinium-enhancing masses in bilateral cerebellopontine angles (large white arrows) with extension into the internal auditory canals (small white arrows), characteristic of vestibular schwannomas. Several extra-axial enhancing masses were present in the posterior fossa and the right middle cranial fossa (black arrows), consistent with meningiomas.

From the Preston Robert Tisch Brain Tumor Center (S.S., A.D., D.A.R., J.N.R., J.J.V.), Departments of Medicine (S.S., A.D., J.N.R., J.J.V.), Surgery (D.A.R., J.N.R.), and Neurobiology (J.N.R.), Duke University Medical Center, Durham, NC.

Disclosure: The authors report no conflicts of interest.

Received August 11, 2006. Accepted in final form November 27, 2006.

Address correspondence and reprint requests to Dr. Sith Sathornsumetee, The Preston Robert Tisch Brain Tumor Center, Department of Medicine, Duke University Medical Center, DUMC 3624, Durham, NC 27710; e-mail: satho001@mc.duke.edu

E14 Copyright @ 2007 by AAN Enterprises, Inc. 


\section{Neurology}

Neurofibromatosis type 2

S. Sathornsumetee, A. DesJardins, D. A. Reardon, et al.

Neurology 2007;68;E14

DOI 10.1212/01.wnl.0000257828.56178.9f

\section{This information is current as of March 26, 2007}

\section{Updated Information \&} Services

References

\section{Subspecialty Collections}

Permissions \& Licensing

Reprints including high resolution figures, can be found at: http://n.neurology.org/content/68/13/E14.full

This article cites 2 articles, 2 of which you can access for free at: http://n.neurology.org/content/68/13/E14.full\#ref-list-1

This article, along with others on similar topics, appears in the following collection(s):

Neurofibromatosis

http://n.neurology.org/cgi/collection/neurofibromatosis

Information about reproducing this article in parts (figures,tables) or in its entirety can be found online at:

http://www.neurology.org/about/about_the_journal\#permissions

Information about ordering reprints can be found online:

http://n.neurology.org/subscribers/advertise

Neurology ${ }^{\circledR}$ is the official journal of the American Academy of Neurology. Published continuously since 1951, it is now a weekly with 48 issues per year. Copyright . All rights reserved. Print ISSN: 0028-3878. Online ISSN: 1526-632X.

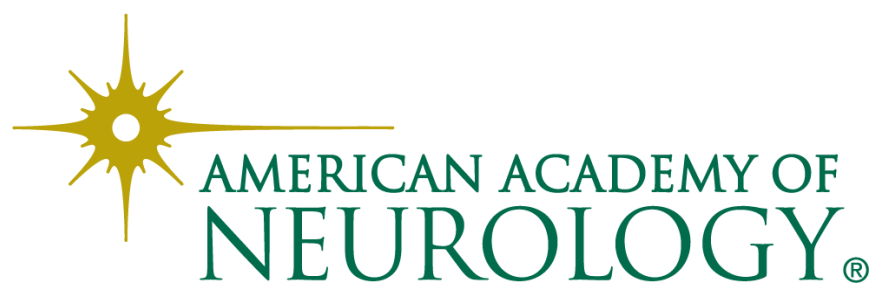

